\title{
CUSTOMER CONCENTRATION AND EXPLORATORY INNOVATION: THE MEDIATING EFFECT OF PERCEIVED PERFORMANCE-REDUCING THREATS
}

\author{
Wanxiao $\mathrm{ZHAO}^{1}$, Chengyuan WANG ${ }^{{ }^{*}}$, Liang WAN ${ }^{1}$, Qiong WANG ${ }^{2}$, Biao LUO ${ }^{3}$ \\ ${ }^{1}$ School of Management, University of Science and Technology of China, Hefei, P.R. China \\ ${ }^{2}$ School of Economics, Hefei University of Technology, Hefei, P.R. China \\ ${ }^{3}$ School of Management, Hefei University of Technology, Hefei, P.R. China
}

Received 12 February 2020; accepted 01 March 2021

\begin{abstract}
A great deal of research attention has been devoted to studying the effects of customer concentration on firm strategic acts. Scholars have also investigated the relationship between customer concentration and firm innovation, but concluded inconsistent findings of such relationship. Furthermore, the underlying mechanism remains unclear. To address these concerns, this study decouples exploratory innovation from firm innovation and introduce performance-reducing threats perceived by the executives as the mediator. Based on the observations of China high-tech listed firms from 2011 to 2018, empirical results show that customer concentration has a U-shaped relationship with exploratory innovation, via the mediating effect of performance-reducing threats perceived by the executives.
\end{abstract}

Keywords: customer concentration, exploratory innovation, performance-reducing threats, executives' perceptions, high-tech companies, strategic acts, mediating effect.

JEL Classification: L20, O30.

\section{Introduction}

Customers are crucial external stakeholders of a firm, and play a significant role in the firm's operational decisions and profitability (Shen et al., 2018; Song \& Wang, 2019). Over the past decade, there has emerged with an ever-increasing tendency of relying on several major customers, such that customer concentration has continued to be raised in firms world widely (Chang et al., 2017). Correspondingly, exploring the consequences of customer concentration becomes increasingly significant and the related issues have also acquired abundant research attentions. For instance, current literatures have indicated that customer concentration has significant effects on firms' strategic activities such as cash holdings (Itzkowitz, 2013) and cost structure (Chang et al., 2017).

${ }^{\star}$ Corresponding author. E-mail: wcy1989@ustc.edu.cn

Copyright (c) 2021 The Author(s). Published by Vilnius Gediminas Technical University

This is an Open Access article distributed under the terms of the Creative Commons Attribution License (http://creativecommons. org/licenses/by/4.0/), which permits unrestricted use, distribution, and reproduction in any medium, provided the original author and source are credited. 
Scholars have also linked customer concentration to firm innovation (Krolikowski \& Yuan, 2017; Shen et al., 2018; Zhou et al., 2019). While prior studies have investigated the effect of customer concentration on firm innovation by using various measurements of innovation empirically, they have concluded inconsistent findings toward such effect. For instance, Shen et al. (2018) concluded a U-shaped relationship between customer concentration and firm innovation; Krolikowski and Yuan (2017) found that a concentrated customer base can positively motivate the firm to innovate; yet Zhou et al. (2019) suggested that the relationship between customer concentration and firm innovation is negative. In addition, how does it happen? The underlying mechanism of the linkage between customer concentration and firm innovation remains unclear. Hence, more studies need to be invested to not only reconcile the inconsistent conclusions, but also explore the ways how customer concentration plays role in firm innovation.

This paper attempts to address these limitations. First, this study decouples exploratory innovation from firm innovation and investigate how customer concentration influences exploratory innovation. A probable reason for the existing inconsistent conclusions toward the effect of customer concentration on firm innovation is that different types of innovation activities (e.g., exploratory innovation versus exploitative innovation) were not distinguished from the innovation measurements in prior studies, and customer concentration may have diverse influences on different types of innovation activities. Second, this paper introduces perceived performance-reducing threats by the executives as the mediating variable, to build the linkage between customer concentration and exploratory innovation. As key social capital and relational resources, customers directly contribute to firm performance (Voss et al., 2008). Customer concentration reflects the relationship between customers and the firm (Krolikowski \& Yuan, 2017), and can cause the executives' concerns of future performance. This paper argues that customer concentration has a U-shaped relationship with executives' perception of performance-reducing threats. Prior studies have indicated that perceived performance-reducing threats of executives may act on exploratory innovation activities (Osiyevskyy \& Dewald, 2015). Hence, via the mediating effect of executives' perceived performance-reducing threats, this study builds the linkage between customer concentration and exploratory innovation.

This study contributes to the extant literature in several ways. First, this study contributes to adding the growing body of the literature on managerial consequences of customer concentration. By decoupling exploratory innovation from firm innovation and introducing the executives' perceptions of performance-reducing threats, this paper reveals a non-linear effects of customer concentration on exploratory innovation. Second, this paper contributes to deepening the understanding of the antecedents of firm innovation, especially illuminating the underlying mechanism. Finally, this study contributes to enriching the literature on the role of managers' perceptions of organizational threats in their strategic decision-makings, by using a novel measurement based on the content analysis.

This paper is organized as the follows. Section 1 reviews the theoretical background and develops hypotheses. Section 2 illustrates the sample selection, variable measurements, and empirical methodology. Section 3 presents primary empirical results. Section 4 checks the robustness of empirical analyses. Section 5 provides discussion of the findings. Finally, the conclusions and limits are inserted. 


\section{Literature review and hypotheses development}

\subsection{Theoretical background of executives' innovation decision-making}

In most organizations, executives play a pivotal role in the decision-making of corporate strategies including innovation decisions (Daft \& Weick, 1984). The literature has been exploring a plenty of antecedents that can influence on executives' innovation decision-making, underpinning on various theoretical bases (Wang et al., 2019; Osiyevskyy \& Dewald, 2015). In this study, the research framework is mainly built on the coupling of cognitive frame theory and prospect theory. Cognitive frame theory argues that because of cognitive limitations, executives will implement innovation activities based on their interpretations of what they have scanned inside and outside the organization (Hahn et al., 2014). Accordingly, their sense-making of innovation decisions would undergo three stages, that are, scanning, interpreting, and responding (Wang et al., 2016; Daft \& Weick, 1984), respectively. Executives in general scan the changes of internal or external environment, including society aspects and organization resources (e.g., customer base). The information cues they gathering are generally ambiguous and selective, in which they generally focus on those things that are facing severe situations. Then, executives interpret their scanning results as opportunities or threats, constructing a gain-frame or loss-frame of decision-marking. According to prospect theory, the gain-frame (loss-frame) will lead executives to take risk-aversion (risk-taking) decisions to respond. Based on the above sense-making process of executives, this study will further argue that both an over-decentralized customer base and a high level of customer concentration would be interpreted as the threats of possible loss of resources by the executives. As a result, executives tend to be risk-seeking and prefer more adventurous or novel activities, reflecting in exploratory innovation.

\subsection{Customer concentration, firm strategic acts, and innovation}

Customer is a thing of relational resources and straight contributes to the revenue of firms (Voss et al., 2008). Customer concentration measures how concentrated a supplier's customer base is, and is one of the most important characteristics of the supplier-customer relationship (Huang et al., 2016). Therefore, customer concentration is in essence related to the composition of operational revenue and has significant influences on the firm's strategic decisions. Based on transaction cost theory, a set of the literature encouraged firms to enhancing customer concentration, given that a high level of customer concentration generally corresponds to low marginal cost of production and transaction (Krolikowski \& Yuan, 2017; Patatoukas, 2012; Pan et al., 2020). Holding a more concentrated customer base can facilitate a firm's resources integration and information sharing along the supplier chain, improving inventory management and operational efficiency and avoiding the bullwhip effect (Irvine et al., 2016; Kelepouris et al., 2008; Krolikowski \& Yuan, 2017). While other scholars objected to it because that customer concentration may have negative consequences. For instance, a more concentrated customer base may result in a higher cost of equity (Dhaliwal et al., 2016), and a larger performance fluctuation. A living case is Lens Technology which supplied phone cover glass to Apple. From 2013 to 2015, Lens Technology's sales revenue to Apple account for 
$40.12 \%, 47.44 \%$, and $48.40 \%$ of its total revenue, respectively. Whereas its total sales revenue decreased $11.56 \%$ in 2016 due to the poor market performance of iPhone $6 s$ series. In addition, the higher the customer concentration, the greater the bargaining power of core customers, and hence the higher probabilities that core customers will squeeze economic profits and occupy commercial credit (Huang et al., 2016; Peng et al., 2019). On the whole, the influences of customer concentration on firm strategic acts deserve to be more investigated.

To our best knowledge, several studies have also investigated the influences of customer concentration on firm innovation. For instance, by using a sample of U.S. firms from 1980 to 2005, Krolikowski and Yuan (2017) suggested that a concentrated customer base motivates firms to invest more in $\mathrm{R} \& \mathrm{D}$ expenditure and become more innovative, reflecting in innovation intensity (measured by the number of applied patents per year), innovation importance (measured by total number of non-self-citations across all applied patents), and innovation efficiency (measured by the quantity of patents for a given amount of R\&D expenditure). Shen et al. (2018) found a U-shaped relationship between customer concentration and firm innovation which was measured by the natural logarithm of $\mathrm{R} \& \mathrm{D}$ expenditures and the ratio of $\mathrm{R} \& \mathrm{D}$ expenditures to total assets, based on the sample of China listed firms. While Zhou et al. (2019) which was also based on a large panel sample of China listed firms, suggested the firm's innovation capability (investment in R\&D) measured by the ratio of R\&D expenditures to operating incomes is negatively correlated with customer concentration. It can be found that prior studies have concluded inconsistent findings regarding the effect of customer concentration on firm innovation. As argued previously, a probable reason lies in the limitation of the measurements, that is, they did not decouple specific innovative activities such as exploratory innovation from firm innovation. Customer concentration may have diverse influences on different types of innovation activities. In addition, more importantly, prior studies have scarcely investigated the underlying mechanism how customer concentration impacts on firm innovation.

\subsection{Customer concentration and perceived performance-reducing threats}

Performance-reducing threats perceived by the executives refer to the perceptions of anticipated or likely losses in revenues and profits in the future (Osiyevskyy \& Dewald, 2015). This study argues that customer concentration would affect perceived performance-reducing threats by the executives, before it acts on the firm's business decisions. Prior studies stated that customer concentration refers to the ratio of major customers' sales to total sales of the firm (Zhou et al., 2019). An over-decentralized customer base implies that the firm needs to allocate its limited capacities to a large number of customers, and hence allocations to per customer decrease, leading to high probabilities of customer turnover. Low stability of customers will momently rouse the executives' worries of performance-reducing. Relatively, a high level of customer concentration suggests a high dependency as well as a low bargaining power of the firm to its major customers (Peng et al., 2019). Given that the firm is scarcely possible to seek out alternatives in a short term, losing a major customer would greatly damage the firm's revenue (Campello \& Gao, 2017; Dhaliwal et al., 2016). For instance, after Huawei was listed in the so-called US entity list, many suppliers who largely relied on Huawei's 
mobile phone business such as NeoPhotonics have been confronting with huge challenges so far. In sum, it can be seen that both low- and high-level of customer concentration will lead the firm's executives to perceive potential threats of performance-reducing.

While customer concentration is moderate, the executives could generally find a balance between the dependency on major customers and buttering other limited customers. In addition, the bargaining power of the firm would also be optimal in the supply chain, and leads to a stable customer base. As a result, the executives are likely to perceive less performance-reducing threats. Therefore, this paper proposes that there exists a non-linear relationship between customer concentration and perceived performance-reducing threats by the executives, as the following:

H1: There exists a U-shaped relationship between customer concentration and performancereducing threats perceived by the executives, such that both low-and high-level of customer concentration lead the executives to perceive more performance-reducing threats.

\subsection{Performance-reducing threats and exploratory innovation}

As previously argued, performance-reducing threats perceived by the executives signify their fears of likely losses in revenues and profits. Hence, when perceiving performance-reducing threats, the executives would construct a loss-frame of decision-marking (Wang et al., 2016). As prospect theory predicted, they are likely to be loss aversion and risk-seeking under the loss-frame (Chattopadhyay et al., 2001; Kahneman \& Tversky, 1979). As a result, the executives would take adventurous actions, such as developing new products and new markets (Wang et al., 2016) and adopting disruptive business models (Osiyevskyy \& Dewald, 2015), namely, exploratory innovation. For instance, above mentioned Lens Technology took measures to develop new business and de-Apple after the large decline in sales by increasing R\&D investments. Hence, this study proposes that:

H2: Performance-reducing threats is positively associated with exploratory innovation.

\subsection{The mediating effect of performance-reducing threats}

Cognitive frame theory has argued that strategic acts including innovation activities are in general the responses of the executives' scanning of organizational situations (e.g., environmental changes and resource losses) that the firm is facing or will face with (Daft \& Weick, 1984). The executives would generally perceive and interpret organizational situations as either opportunities or threats (Daft \& Weick, 1984). Once the executives perceive likely-loss threats which imply probably losses of specific resource (Ocasio, 1995), they will interpret them as the weakening competitiveness of the firm (Wang et al., 2016). As mentioned above, the executives would frame a loss decision making context and hence take risky actions to hedge likely resource losses.

When it comes to customer concentration, both low- and high-level of customer concentration would arouse the executives' perceptions of performance-reducing threats caused by fears of likely losses in customer resources, and then lead them to adopt exploratory innovation activities. The theoretical analysis argued above has linked customer concentration and performance-reducing threats to exploratory innovation, suggesting that customer 
concentration can influence firm exploratory innovation via performance-reducing threats perceived by the executives. Hence, this study proposes that:

H3: The relationship between customer concentration and exploratory innovation is mediated by performance-reducing threats perceived by the executives.

\section{Methods}

\subsection{Data collection}

Following prior studies (Bang et al., 2016; Minakov et al., 2017), this study tests hypotheses based on the data of firms in the high-tech industries including telecommunications, radio and television and satellite transmission services, internet and related services and software and information technology services. The data was collected from China listed high-tech companies. Given that most listed companies in China began to disclose the information of major customers since 2010, the observation period starts from 2011 to 2018. The data on customer concentration and firm-level characteristics is obtained from the database of China Stock Market and Accounting Research (CSMAR). The original data for calculating exploratory innovation was based on the text content of the section of management discussion and analysis in the firms' annual reports, which was also collected from CSMAR. The initial data for calculating the executives' perception of performance-reducing threats was collected from Chinese Research Data Services (CNRDS). Finally, an unbalanced panel data of 793 observations covering 99 listed high-tech companies during 2011 and 2018 was obtained.

\subsection{Variable measurements}

Customer concentration. The officially disclosed ratio of sales to top five customers to total sales is used to measure customer concentration. Such measurement is also widely used in prior studies (Chang et al., 2017; Dhaliwal et al., 2016; Huang et al., 2016). The ratio is calculated as

$$
\text { CC_Top5 }=\frac{\sum_{i=1}^{i=5} \text { Sales }_{i, t}}{\text { Totalsales }_{t}}
$$

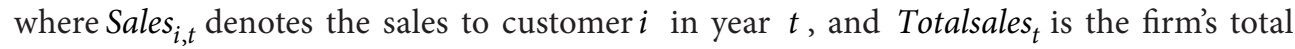
sales in year $t$.

Exploratory innovation. March (1991) stated that "exploration" includes things captured by terms such as search, variation, risk taking, experimentation, play, flexibility, discovery, innovation. Previous studies have mainly used questionnaire-based approach (Chen et al., 2018; Xie \& Gao, 2018; Wang et al., 2019; Wu \& Peng, 2020) or patent-based (Yu \& Chen, 2019; Xu et al., 2017; Lu \& Pohkam, 2019) indicators to measure exploratory innovation. However, despite of potential heterogeneity, endogeneity and other problems (Ugur, 2013; Gatti et al., 2015), the questionnaire-based approach may also lack generalizability and applicability for a broad sample context (Uotila et al., 2009), such as the sample of publicly listed firms in this study. In addition, the patent-based indicators are hardly to decouple 
strictly exploration activities from the firm's innovation. Furthermore, it is often controversial whether above approaches are consistent with the original conceptual definition of exploration innovation proposed by March (1991) (Ugur, 2013; Uotila et al., 2009).

To address these concerns, this study employs an approach of content analysis that were advocated by Uotila et al. (2009) and further extended in Chinese context by Luo et al. (2016) to measure exploratory innovation (Luo et al., 2016; Uotila et al., 2009). The measurement steps are as follows. First, this study replicated the keywords that embody "exploratory" proposed by Luo et al. (2016), and translated them into Chinese. In addition, this study invited two doctoral candidates to check and confirm Chinese translated words. The words were discussed and revised until a consensus was reached. Second, this study downloaded annual reports of the sample firms and then extracted the structured directors' reports from annual reports. To measure exploratory activities more precisely, this study further extracted the discussion parts of the firms' development strategy and business plan in the next annual year, and organized them into text files. Third, this study employed a widely used Chinese text analysis software ROST CM6 which was also used by Luo et al. (2016) to execute word segmentation, and count the length of each text file and the frequency of exploratory related keywords. Finally, exploratory innovation of a firm is measured by using the sum of the frequency of all exploratory related keywords dividing by the length of text file of the firm.

Performance-reducing threats perceived by the executives. The questionnaire-based method was also utilized to measure the executives' perceptions of performance-reducing threats in prior studies (Osiyevskyy \& Dewald, 2015). However, it also lacks realizability for us to obtain data considering the sample in this study is comprised of publicly listed firms. Hence, this study employs an alternative approach which is also based on the content analysis method as the proxy to measure performance-reducing threats perceived by the executives.

Recently, using the emotions or tones reflected in the management discussion and analysis of annual reports to predict the future performance of listed companies has largely received research attention (Bochkay \& Levine, 2019; Li, 2010; Hajek et al., 2014). Prior studies have suggested that emotions in the annual reports could imply the executives' performance anticipation in the coming years and are positively related to the firm's further performance. The more negative emotions, the more threats that the executives perceived and the larger probabilities of reducing performance in the further, and vice versa. Specifically, the positive (or negative) emotions are measure by the ratio of positive (or negative) words to total words (Baginski et al., 2018).

This paper utilizes the relative degree of negative emotions versus positive emptions reflected in the annual reports to as the proxy of measuring performance-reducing threats perceived by the executives, which is calculated as

$$
\text { PRT }=\frac{\text { Ratio of negative words }- \text { Ratio of postive words }}{\text { Ratio of negative words }+ \text { Ratio of postive words }}
$$

where PRT denotes performance-reducing threats perceived by the executives.

The database of Chinese Research Data Services (CNRDS) provides the ratios of both positive and negative words of China listed firms from 1999 to 2018. CNRDS database adopts the artificial intelligence algorithm to judge and identify positive and negative words in the 
management discussion and analysis of annual reports. The dictionary that CNRDS utilizes is based on the Chinese translation from the English dictionary of Loughran \& McDonald (2011). The indicators of emotional words of CNRDS have been used to predict the future performance in prior studies (Xie \& Lin, 2015; Jia \& Bian, 2019).

Control variables. This study controls for a set of firm-level characteristics including firm size, profitability, property, firm age, the proportion of tangible assets, situation of cash flows and leverages that were widely used in prior studies (Krolikowski \& Yuan, 2017; Shen et al., 2018; Wang et al., 2019). The size of sample firms is measured by the nature logarithm of total year-end assets (Size). This study also controls the profitability of the firms by using returns on assets $(R O A)$. The property is a dualistic variable, such that it equals one if the sample firm is a state-owned enterprise otherwise equals zero (Property). The proportion of tangible assets is calculated by the ratio of tangible assets to total assets (Tangible_ratio). The situation of cash flows is estimated by the ratio of reported cash flows to total assets (Cash_flows). Leverage is measured by the ratio of total debts of total assets (Leverages). In addition, this study controls for industry fixed effect and year fixed effect in the regression models.

Table 1 presents the definitions of above variables.

Table 1. Definitions of variables

\begin{tabular}{|c|c|c|c|}
\hline Type & Variable & Symbol & Description \\
\hline Dependent var. & Customer concentration & CC_Top5 & $\begin{array}{l}\text { The ratio of sales to top five } \\
\text { customers to total sales }\end{array}$ \\
\hline Independent var. & Exploratory innovation & ER & $\begin{array}{l}\text { Exploration strength for the next } \\
\text { year }\end{array}$ \\
\hline Mediating var. & $\begin{array}{l}\text { Performance-reducing threats } \\
\text { perceived by the executives }\end{array}$ & PRT & $\begin{array}{l}\text { The perceptions of anticipated or } \\
\text { likely losses in revenues and profits } \\
\text { in the future }\end{array}$ \\
\hline \multirow{9}{*}{ Control var. } & Firm size & Size & $\begin{array}{l}\text { The nature logarithm of total year- } \\
\text { end assets }\end{array}$ \\
\hline & Profitability & ROA & Return on assets \\
\hline & Firm age & Age & $\begin{array}{l}\text { The number of years the enterprise } \\
\text { has been established }\end{array}$ \\
\hline & Property & Property & $\begin{array}{l}\text { Equals one if the sample firm is a } \\
\text { state-owned enterprise otherwise } \\
\text { equals zero }\end{array}$ \\
\hline & $\begin{array}{l}\text { The proportion of tangible } \\
\text { assets }\end{array}$ & $\begin{array}{l}\text { Tangible } \\
\text { ratio }\end{array}$ & $\begin{array}{l}\text { The ratio of tangible assets to total } \\
\text { assets }\end{array}$ \\
\hline & Cash flows & Cash_flows & $\begin{array}{l}\text { The ratio of reported cash flows to } \\
\text { total assets }\end{array}$ \\
\hline & Leverages & Leverages & $\begin{array}{l}\text { The ratio of total debts of total } \\
\text { assets }\end{array}$ \\
\hline & Industry fixed effect & Ind & Dummy Variable \\
\hline & Year fixed effect & Year & Dummy Variable \\
\hline
\end{tabular}


Table 2 reports descriptive statistics of the variables. There exist large variances of both customer concentration and exploratory innovation. The mean of exploratory innovation is 12.36 and its standard deviation is 5.08. The maximum of exploratory innovation is almost triple the mean. Similarly, the average of the ratio of sales to top five customers is $25.79 \%$, and the maximum reaches $90.85 \%$ while the minimum is only $0.8 \%$.

Table 2. Descriptive statistics

\begin{tabular}{|l|c|c|c|c|c|}
\hline \multicolumn{1}{|c|}{ Variables } & Mean & St. Dev. & Min & Max & Obs. \\
\hline Exploratory innovation & 12.3641 & 5.0835 & 0 & 34.2531 & 790 \\
\hline CC_Top5 & 25.7862 & 17.6330 & 0.8000 & 90.8500 & 776 \\
\hline PRT & -0.4824 & 0.1288 & -0.8269 & 0.0279 & 789 \\
\hline Size & 21.7626 & 1.0807 & 19.6399 & 27.1464 & 792 \\
\hline Property & 0.2416 & 0.4284 & 0 & 1 & 778 \\
\hline ROA & 0.0458 & 0.0749 & -0.9268 & 0.4819 & 792 \\
\hline Age & 20.2349 & 5.3094 & 10 & 39 & 792 \\
\hline Tangible_ratio & 0.1199 & 0.1352 & 0.0005 & 0.7511 & 784 \\
\hline Leverages & 0.3246 & 0.1810 & 0.0214 & 0.9606 & 784 \\
\hline Cash_flows & 0.0478 & 0.0761 & -0.2836 & 0.4756 & 784 \\
\hline
\end{tabular}

\subsection{Empirical methodology}

To explore the relationship between customer concentration and exploratory innovation as well as the mediating effect, this study utilized the following regression models (Guo, 2018; Baron \& Kenny, 1986):

$$
\begin{gathered}
P R T_{j, t+1}=\beta_{0}+\beta_{1} \text { CC_Top5 } 5_{j, t}+\beta_{2}\left(C C_{-} \text {Top } 5_{j, t}\right)^{2}+ \\
\beta_{3} \text { Controls }_{j, t}+\text { Ind }+ \text { Year }+\varepsilon_{j, t} ; \\
E R_{j, t+1}=\delta_{0}+\delta_{1} P R T_{j, t+1}+\delta_{2} \text { Controls }_{j, t}+\text { Ind }+ \text { Year }+\varepsilon_{j, t} ; \\
E R_{j, t+1}=\gamma_{0}+\gamma_{1} \text { CC_Top5 } 5_{j, t}+\gamma_{2}\left(C C_{-} \text {Top } 5_{j, t}\right)^{2}+ \\
\gamma_{4} \text { Controls }_{j, t}+\text { Ind }+ \text { Year }+\varepsilon_{j, t} ; \\
E R_{j, t+1}=\alpha_{0}+\alpha_{1} \text { CC_Top } 5_{j, t}+\alpha_{2}\left(C C_{-} \text {Top } 5_{j, t}\right)^{2}+ \\
\alpha_{3} P R T_{j, t+1}+\alpha_{4} \text { Controls }_{j, t}+\text { Ind }+ \text { Year }+\varepsilon_{j, t},
\end{gathered}
$$

where CC_Top $5_{j, t}$ denotes customer concentration of firm $j$ in year $t, E R$ refers to exploratory innovation, $P R T$ is the mediating variable, i.e., performance-reducing threats perceived by the executives, and Controls is the vector that contains control variables described previously. Ind and Year are dummy variables to control industry fixed effect and year fixed effect, respectively. 


\section{Empirical results}

Table 3 is the matrix of correlations between variables.

Table 3. Correlations

\begin{tabular}{|c|c|c|c|c|c|c|c|c|c|c|}
\hline $\begin{array}{l}\text { Va- } \\
\text { riables }\end{array}$ & $\begin{array}{l}\text { Explo- } \\
\text { ratory } \\
\text { inno- } \\
\text { vation }\end{array}$ & CC_Top5 & PRT & Size & State & ROA & Age & $\begin{array}{l}\text { Tan- } \\
\text { gible_- } \\
\text { ratio }\end{array}$ & $\begin{array}{l}\text { Lever- } \\
\text { ages }\end{array}$ & $\begin{array}{l}\text { Cash_ } \\
\text { flows }\end{array}$ \\
\hline $\begin{array}{l}\text { Explo- } \\
\text { ratory } \\
\text { inno- } \\
\text { vation }\end{array}$ & 1 & & & & & & & & & \\
\hline $\begin{array}{l}\mathrm{CC}_{-} \\
\text {Top5 }\end{array}$ & $0.1222^{* * *}$ & 1 & & & & & & & & \\
\hline PRT & -0.0542 & $0.1330^{* * *}$ & 1 & & & & & & & \\
\hline Size & -0.0113 & $-0.2823^{* * *}$ & $-0.1305^{* * *}$ & 1 & & & & & & \\
\hline $\begin{array}{l}\text { Pro- } \\
\text { perty }\end{array}$ & $0.0901^{* *}$ & 0.0109 & $-0.1562^{* * *}$ & $0.3431^{* * *}$ & 1 & & & & & \\
\hline ROA & 0.0089 & $-0.0859^{* *}$ & $-0.2921^{* * *}$ & 0.0465 & -0.0374 & 1 & & & & \\
\hline Age & 0.0356 & -0.0240 & 0.0033 & 0.0499 & 0.0415 & 0.0244 & 1 & & & \\
\hline $\begin{array}{l}\text { Tan- } \\
\text { gible_- } \\
\text { ratio }\end{array}$ & -0.0146 & $-0.1414^{* * *}$ & -0.0162 & $0.1830^{* * *}$ & $0.2117^{* * *}$ & $-0.1058^{* * *}$ & $0.1021^{* * *}$ & 1 & & \\
\hline $\begin{array}{l}\text { Leve- } \\
\text { rages }\end{array}$ & 0.0398 & $-0.0776^{* *}$ & $0.0594^{*}$ & $0.3525^{* * *}$ & $0.2656^{* * *}$ & $-0.2122^{* * *}$ & $0.0738^{* *}$ & $0.1289^{* * *}$ & 1 & \\
\hline $\begin{array}{l}\text { Cash_ } \\
\text { flows }\end{array}$ & 0.0151 & $-0.1717^{* * *}$ & $-0.1510^{* * *}$ & $0.1253^{* * *}$ & 0.0329 & $0.4030^{* * *}$ & -0.0041 & $0.2672^{* * *}$ & $-0.0682^{*}$ & 1 \\
\hline
\end{tabular}

Notes: ${ }^{*}{ }^{* *}$, and ${ }^{* *}$ denote the significant levels of $\mathrm{p}<0.1, \mathrm{p}<0.05$, and $\mathrm{p}<0.01$, respectively.

To test above hypotheses, this study uses the OLS method with fixed-effects panel regressions. Drawing on prior studies (Fernhaber \& Patel, 2012), this study centres CC_Top5 before calculating its square values. In addition, this study further executes a formal test by checking the coefficients of the lower and upper bound of the U-shaped curve following the guidance of Haans et al. (2016).

Table 4 reports the empirical results. Model 1 shows the relationship between customer concentration and performance-reducing threats. The result indicates that the coefficient of the square term of customer concentration is positively at the $5 \%$ significance level $(\beta=0.00003, p<0.05)$. In addition, the slope at the lower bound of such $U$-shaped relationship is downward at the $5 \%$ significance level $(\beta=-0.0020, p<0.05)$, and the slope of the upper bounder is positive at the $1 \%$ significance level $(\beta=0.0034, \mathrm{p}<0.01)$. These suggest that there indeed exists a U-shaped relationship between customer concentration and performance-reducing threats perceived by the executives (Haans et al., 2016; Lind \& Mehlum, 2010). Hence, Hypothesis 1 is supported.

Model 2 indicates the relationship between performance-reducing threats perceived by the executives and exploratory innovation. The result shows that performance-reducing 
Table 4. Primary empirical results

\begin{tabular}{|c|c|c|c|c|}
\hline & PRT & \multicolumn{3}{|c|}{ Exploratory innovation } \\
\hline & (1) & (2) & (3) & (4) \\
\hline CC_Top5 & $\begin{array}{c}-0.0005 \\
(-1.00)\end{array}$ & & $\begin{array}{c}-0.0181 \\
(-0.78)\end{array}$ & $\begin{array}{c}-0.0176 \\
(-0.76)\end{array}$ \\
\hline CC_Top5 square & $\begin{array}{c}0.00003^{* *} \\
(2.45)\end{array}$ & & $\begin{array}{c}0.0013^{* *} \\
(2.22)\end{array}$ & $\begin{array}{c}0.0012^{* *} \\
(2.05)\end{array}$ \\
\hline PRT & & $\begin{array}{c}4.0191^{* *} \\
(2.11)\end{array}$ & & $\begin{array}{c}3.8423^{* *} \\
(1.99)\end{array}$ \\
\hline Size & $\begin{array}{l}-0.0040 \\
(-0.40)\end{array}$ & $\begin{array}{l}-0.6026 \\
(-1.25)\end{array}$ & $\begin{array}{l}0.5751 \\
(-1.17)\end{array}$ & $\begin{array}{c}-0.6262 \\
(-1.27)\end{array}$ \\
\hline Property & $\begin{array}{l}0.0268 \\
(0.48)\end{array}$ & $\begin{array}{c}-4.8072^{*} \\
(-1.78)\end{array}$ & $\begin{array}{c}-4.6559^{*} \\
(-1.72)\end{array}$ & $\begin{array}{c}-4.7782^{*} \\
(-1.77)\end{array}$ \\
\hline ROA & $\begin{array}{c}-0.3158^{* * *} \\
(-4.85)\end{array}$ & $\begin{array}{c}-1.8961 \\
(-0.59)\end{array}$ & $\begin{array}{c}-3.7620 \\
(-1.18)\end{array}$ & $\begin{array}{c}-2.6232 \\
(-0.81)\end{array}$ \\
\hline Age & $\begin{array}{c}0.0008 \\
(1.06)\end{array}$ & $\begin{array}{l}-0.0147 \\
(-0.39)\end{array}$ & $\begin{array}{c}-0.0153 \\
(-0.40)\end{array}$ & $\begin{array}{c}-0.0180 \\
(-0.47)\end{array}$ \\
\hline Tangible_ratio & $\begin{array}{c}0.1433^{* * *} \\
(2.73)\end{array}$ & $\begin{array}{l}0.5457 \\
(0.22)\end{array}$ & $\begin{array}{l}1.3354 \\
(0.52)\end{array}$ & $\begin{array}{l}0.5917 \\
(0.23)\end{array}$ \\
\hline Leverages & $\begin{array}{c}-0.0798^{* *} \\
(-2.29)\end{array}$ & $\begin{array}{l}0.2277 \\
(0.13)\end{array}$ & $\begin{array}{c}-0.2317 \\
(-0.14)\end{array}$ & $\begin{array}{l}0.0811 \\
(0.05)\end{array}$ \\
\hline Cash_flows & $\begin{array}{l}-0.0877 \\
(-1.48)\end{array}$ & $\begin{array}{l}0.9697 \\
(0.34)\end{array}$ & $\begin{array}{l}0.3574 \\
(0.12)\end{array}$ & $\begin{array}{l}0.6258 \\
(0.22)\end{array}$ \\
\hline Ind & Yes & Yes & Yes & Yes \\
\hline Year & Yes & Yes & Yes & Yes \\
\hline R-square & 0.3528 & 0.0531 & 0.0549 & 0.0615 \\
\hline \multicolumn{5}{|l|}{ U-test } \\
\hline Lower bound & $\begin{array}{c}-0.0020^{* *} \\
(-1.98)\end{array}$ & & $\begin{array}{c}-0.0832^{* *} \\
(-1.73)\end{array}$ & $\begin{array}{c}-0.0779^{*} \\
(-1.62)\end{array}$ \\
\hline Upper bound & $\begin{array}{c}0.0034^{* * *} \\
(2.59)\end{array}$ & & $\begin{array}{c}0.1514^{* * *} \\
(2.40)\end{array}$ & $\begin{array}{c}0.1395^{* *} \\
(2.20)\end{array}$ \\
\hline Obs. & 751 & 766 & 752 & 750 \\
\hline
\end{tabular}

Notes: ${ }^{*},{ }^{* *}$, and ${ }^{* * *}$ denote the significant levels of $\mathrm{p}<0.1, \mathrm{p}<0.05$, and $\mathrm{p}<0.01$, respectively. t-statistics are reported in the parentheses.

threats have positively influence on the firms' exploratory innovation, at the $5 \%$ significance level $(\beta=4.0191, \mathrm{p}<0.05)$. It is in line with the findings in prior studies (Osiyevskyy \& Dewald, 2015). Thus, Hypothesis 2 is supported.

Model 3 shows that regardless of performance-reducing threats, the curve of the relationship between customer concentration and exploratory innovation is also U-shaped $(\beta=0.0013$, t-statistics $=2.22)$. Hence, Model 1 to 3 have provided initial evidence for the mediating effect of performance-reducing threats perceived by the executives on the relationship between customer concentration and exploratory innovation. To further confirm 
such mediating effect, this study implements additional regression via Eq. (6). The results in Model 4 show that after adding performance-reducing threats, both the coefficient and the significance level ( $t$-statistics) of the square term of customer concentration $(\beta=0.0012$, $t$ statistics $=2.05$ ) reduce slightly relative to those in Model 3 . All the above results suggest that customer concentration can play a U-shaped role in exploratory innovation via the executives' perceptions of performance-reducing threats. Therefore, Hypothesis 3 is also supported.

\section{Robustness tests}

To test the robustness of empirical results, this section executes additional checks. First, to minimize the potential influences of extreme values or spurious outliers, this section winsorizes the top $1 \%$ and bottom $1 \%$ of all continuous variables (Faleye et al., 2013), and then run the regressions as above. The results are showed in Table 5. It indicates that above empirical results are robust under implementing winsorization.

Table 5. Robustness tests via winsorization

\begin{tabular}{|l|c|c|c|c|}
\hline \multirow{2}{*}{} & PRT & \multicolumn{3}{|c|}{ Exploratory innovation } \\
\cline { 2 - 5 } & $(5)$ & $(6)$ & $(7)$ & $(8)$ \\
\hline CC_Top5 & $\begin{array}{c}-0.0005 \\
(-1.10)\end{array}$ & & $\begin{array}{c}-0.0172 \\
(-0.75)\end{array}$ & $\begin{array}{c}-0.0165 \\
(-0.72)\end{array}$ \\
\hline CC_Top5 square & $\begin{array}{c}0.00003^{* *} \\
(2.50)\end{array}$ & & $\begin{array}{c}0.0014^{* *} \\
(2.21)\end{array}$ & $\begin{array}{c}0.0013^{* *} \\
(2.03)\end{array}$ \\
\hline PRT & & $4.1249^{* *}$ & & $\begin{array}{c}3.9684^{* *} \\
(2.00)\end{array}$ \\
\hline Controls & Yes & Yes & Yes & Yes \\
\hline Ind & Yes & Yes & Yes & Yes \\
\hline Year & Yes & Yes & Yes & Yes \\
\hline R-square & 0.3713 & 0.0564 & 0.0579 & 0.0649 \\
\hline U-test & & & & $-0.0837^{* *}$ \\
\hline Lower bound & $0.0021^{* *}$ & & $(-1.73)$ & $\begin{array}{c}-0.0776^{*} \\
(2.09)\end{array}$ \\
\hline Upper bound & $-0.0027^{* * *}$ & & $0.1216^{* * *}$ & $0.1113^{* *}$ \\
\hline Obs. & $(-2.64)$ & & $7.41)$ & $(2.19)$ \\
\hline
\end{tabular}

Notes: ${ }^{*}{ }^{* *}$, and ${ }^{* * *}$ denote the significant levels of $\mathrm{p}<0.1, \mathrm{p}<0.05$, and $\mathrm{p}<0.01$, respectively. t-statistics are reported in the parentheses.

Second, this section adopts another indicator, the ratio of sales to the largest customer (denoted by CC_Top1), to measure customer concentration. The ratio of sales to the largest customer was often used as a proxy of the customer concentration (Kim \& Lee, 2019; Campello \& Gao, 2017; Wen et al., 2020).Though the China Security Regulatory Commission requires that listed firms should disclose the ratio of sales to their top five customers relative 
to total sales, the firms can voluntarily disclose the detailed ratios of each of the top five customers. Hence, there were many firms which did not disclose the ratio of sales to the largest customer, causing a large number of missing values of CC_Top1. To reduce the potential selection bias caused by missing values (Flannery \& Rangan, 2006), this section adds a dummy variable (Dummy) that equals one if the firm has disclosed CC_Top1 otherwise equals zero. Correspondingly, CC_Top1 equals zero for the firms whose Dummy is zero. Empirical results are reported in Table 6. It can be seen that above empirical findings are still robust.

Table 6. Robustness tests results of fixed-effect regression analysis

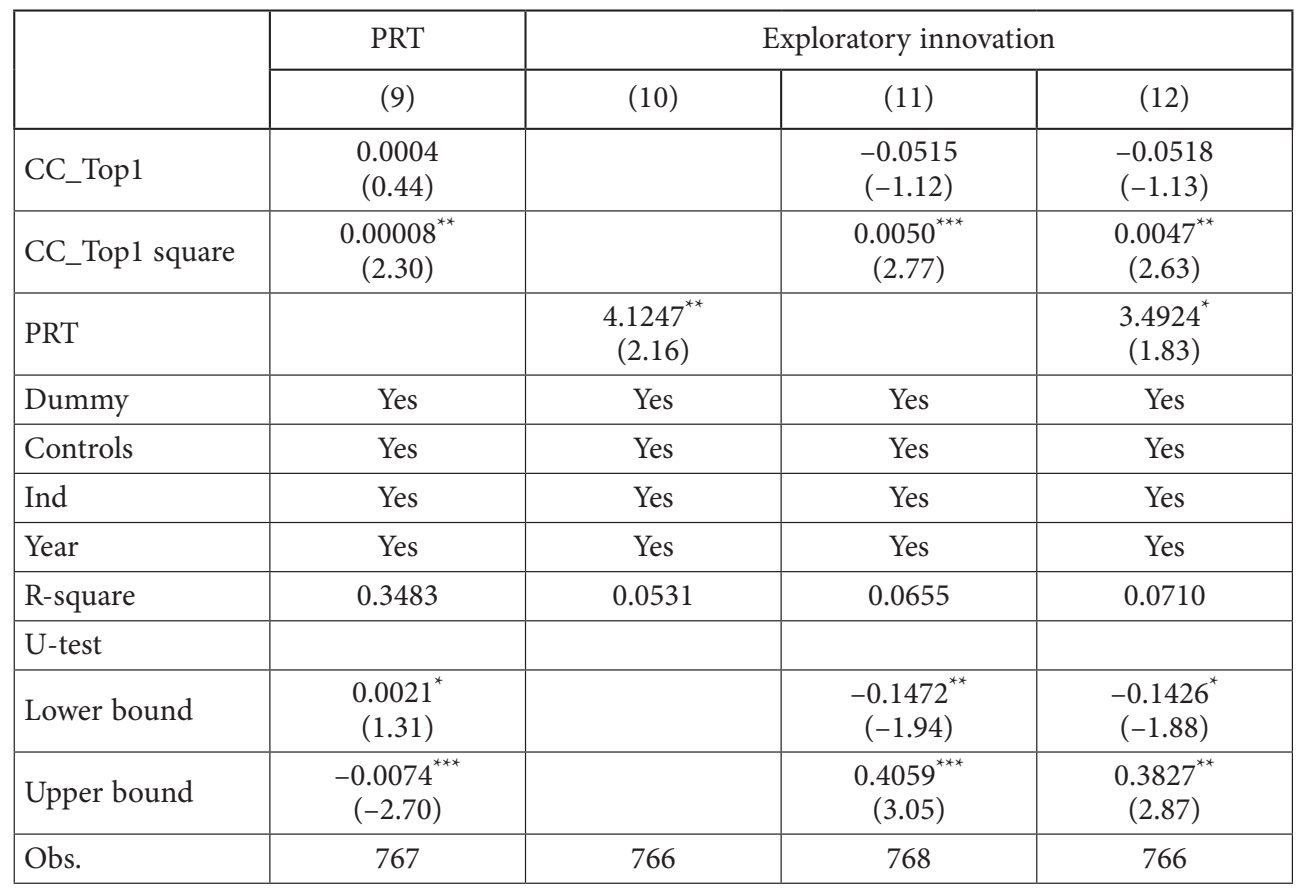

Notes: ${ }^{*},{ }^{* *}$, and ${ }^{* * *}$ denote the significant levels of $\mathrm{p}<0.1, \mathrm{p}<0.05$, and $\mathrm{p}<0.01$, respectively. t-statistics are reported in the parentheses.

\section{Discussion}

With an ever-increasing tendency of relying on several major customers in firms, understanding how customer concentration influences firm innovation has both theoretical value and practical significance. In addition, though the effects of customer concentration on firm strategic acts including firm innovation have been largely investigated, the underlying influence paths of such effects deserve more attentions. To this end, underpinning on prospect theory (Chattopadhyay et al., 2001; Kahneman \& Tversky, 1979) and cognitive frame theory (Daft \& Weick, 1984), this study builds the conceptual model of a non-linear relationship between customer concentration and firm exploratory innovation, via the mediating effect of the executives' perceptions of performance-reducing threats. 
The findings are important for the existing literature. First, these findings account for the conflicting results toward how customer concentration can affect firm innovation in prior studies. As previously mentioned, several prior studies have investigated the influence of customer concentration on firm innovation, yet concluded discrepant findings on such influence (Krolikowski \& Yuan, 2017; Shen et al., 2018; Zhou et al., 2019). This study proposes that a plausible explanation for this is the limitation of their measurements of firm innovation, in which they did not decouple specific innovative activities such as exploratory innovation from firm innovation, while customer concentration may have diverse influences on different types of innovation activities. In response, this study investigates and thereby finds a non-linear influence of customer concentration on exploratory innovation by decoupling the latter from firm innovation. Second, in comparison to prior studies, this study takes a step forward by investigating the underlying mechanism why customer concentration can affect firm innovation activities. These empirical analyses verify that the executives' perceptions of performance-reducing threats indeed mediate the non-linear relationship between customer concentration on exploratory innovation. Hence, these findings offer a new idea to understand the relationship between customer base and firm innovation activities. Finally, given that a large number of prior studies have utilized the questionnaire-based method to measure the executives' perceptions of performance-reducing threats, yet lacking realizability to obtain data form publicly listed firms, the empirical analysis method provides a novel and feasible way to measure the executives' perceptions of performance-reducing threats for the sample comprised of publicly listed firms, based on the emotions or tones reflected in the annual reports. In conclusion, this paper enriches our understandings of both the consequences of customer concentration and the antecedents of firm exploratory innovation, and develops the knowledge of the underlying mechanism why customer base can influence on the firm's strategic acts.

These findings have also important managerial implications. Executives should "suit the remedy to the case" when they perceive performance-reducing threats, and avoid adopting exploratory innovation across the board, which may put firms at a higher risk and is not conducive to the stable development of firms (Wang et al., 2016). In addition, the executives could generally seek a balance between the dependency on major customers and buttering other limited customers when customer concentration is moderate, such that the firm can achieve a situation where they are not squeezed by core customers on their economic profits and the bargaining power of the firm would also be optimal in the supply chain. Furthermore, firms should pick executives who are sensitive to performance-reducing threats. A sensitive executive often can predicate potential crises and help the firm avoid dropping in dilemmas. In contrast, an insensitive executive may lag behind performance-reducing threats and cause the firm to decline.

\section{Conclusions}

Based on a sample data collected from Chinese high-tech listed firms between 2011 and 2018, this study empirically investigates the conceptual model, by utilizing the text content analysis 
and quantitative methods. These empirical results demonstrate that there exists a U-shaped influence of customer concentration on the executives' perceptions of performance-reducing threats, which in turn positively affect the firm's exploratory innovation. Since an over-decentralized customer base implies the dispersed allocation of limited capacities, leading to high probabilities of customer turnover and low stability of customers. While a high level of customer concentration suggests a high dependency as well as a low bargaining power of the firm to its major customers, given that the firm is scarcely possible to seek out alternatives in a short term, losing a major customer would greatly damage the firm's revenue. Hence, when a firm's customer concentration is either at the high-level or at the low-level, its executives would perceive high-level threats of anticipated performance-reducing. Prospect theory has suggested that when perceiving performance-reducing threats, the executives are likely to be loss aversion and risk-seeking. Accordingly, the executives are likely to take risky strategic acts, e.g., adopting more exploratory activities such as developing new products and extending new markets, so as to mitigate their fears as cognitive frame theory argued. In contrast, while if customer concentration is at an appropriate level, the perceptions of performancereducing threats would largely weaken, and hence exploratory innovation acts are likely to be decreased.

There have also limitations in this study. As shown in these empirical results, both the coefficient and the significance level of the relationship between customer concentration and exploratory innovation merely reduce slightly after adding performance-reducing threats. It implies that there might exist other potential factors which can play significant roles in mediating their relationship. Future studies can put efforts into identify other potential mediating variables.

\section{Funding}

This work was supported by the National Natural Science Foundation of China under Grant Nos. 71701193, 71804040, and 71804174; and Philosophy \& Social Science Project of Anhui Province under Grant No. AHSKQ2019D026.

\section{Author contributions}

Wanxiao Zhao, Chengyuan Wang, and Biao Luo conceived the study and were responsible for the research design and development of the data analysis. Wanxiao Zhao, Liang Wan, and Qiong Wang were responsible for data collection, analysis and interpretation. Wanxiao Zhao and Chengyuan Wang wrote the first draft of the article.

\section{Disclosure statement}

Authors declare that there is no competing financial, professional, or personal interest from other parties. 


\section{References}

Baginski, S. P., Demers, E., Kausar, A., \& Yu, Y. J. (2018). Linguistic tone and the small trader. Accounting, Organizations and Society, 68-69, 21-37. https://doi.org/10.1016/j.aos.2018.03.005

Bang, N., Yu, X., Melewarc, T. C., \& Guptad, S. (2016). Critical brand innovation factors (CBIF): Understanding innovation and market performance in the chinese high-tech service industry. Journal of Business Research, 69(7), 2471-2479. https://doi.org/10.1016/j.jbusres.2016.02.016

Baron, R. M., \& Kenny, D. A. (1986). The moderator-mediator variable distinction in social psychological research: Conceptual, strategic, and statistical considerations. Journal of Personality and Social Psychology, 51(6), 1173-1182. https://doi.org/10.1037/0022-3514.51.6.1173

Bochkay, K., \& Levine, C. B. (2019). Using MD\&A to improve earnings forecasts. Journal of Accounting, Auditing \& Finance, 34(3), 458-482. https://doi.org/10.1177/0148558X17722919

Campello, M., \& Gao, J. (2017). Customer concentration and loan contract terms. Journal of Financial Economics, 123(1), 108-136. https://doi.org/10.1016/j.jfineco.2016.03.010

Chang, H., Hall, C. M., \& Paz, M. (2017). Customer concentration, cost structure, and performance. AAA 2015 Management Accounting Section (MAS) Meeting. https://doi.org/10.2139/ssrn.2482777

Chattopadhyay, P., Glick, W. H., \& Huber, G. P. (2001). Organizational actions in response to threats and opportunities. Academy of Management Journal, 44(5), 937-955. https://doi.org/10.5465/3069439

Chen, M., Yang, Z., Dou, W., \& Wang, F. (2018). Flying or dying? Organizational change, customer participation, and innovation ambidexterity in emerging economies. Asia Pacific Journal of Management, 35(1), 97-119. https://doi.org/10.1007/s10490-017-9520-5

Daft, R. 1., \& Weick, K. E. (1984). Toward a model of organizations as interpretation systems. Academy of Management Review, 9(2), 284-295. https://doi.org/10.5465/amr.1984.4277657

Dhaliwal, D., Judd, J. S., Serfling, M., \& Shaikh, S. (2016). Customer concentration risk and the cost of equity capital. Journal of Accounting and Economics, 61(1), 23-48.

https://doi.org/10.1016/j.jacceco.2015.03.005

Faleye, O., Reis, E., \& Venkateswaran, A. (2013). The determinants and effects of CEO-employee pay ratios. Journal of Banking \& Finance, 37(8), 3258-3272. https://doi.org/10.1016/j.jbankfin.2013.03.003

Fernhaber, S. A., \& Patel, P. C. (2012). How do young firms manage product portfolio complexity? The role of absorptive capacity and ambidexterity. Strategic Management Journal, 33(13), 1516-1539. https://doi.org/10.1002/smj.1994

Flannery, M. J., \& Rangan, K. P. (2006). Partial adjustment toward target capital structures. Journal of Financial Economics, 79(3), 469-506. https://doi.org/10.1016/j.jineco.2005.03.004

Gatti, C., Volpe, L., \& Vagnani, G. (2015). Interdependence among productive activities: Implications for exploration and exploitation. Journal of Business Research, 68(3), 711-722. https://doi.org/10.1016/j.jbusres.2014.07.011

Guo, R. (2018). Strategic decision-making logics, entrepreneurial capability and opportunity exploitation in high-tech new ventures. Journal of Business Economics and Management, 19(2), 235-252. https://doi.org/10.3846/jbem.2018.5201

Haans, R. F. J., Pieters, C., \& He, Z.-L. (2016). Thinking about U: Theorizing and testing U- and inverted U-shaped relationships in strategy research. Strategic Management Journal, 37(7), 1177-1195. https://doi.org/10.1002/smj.2399

Hahn, T., Preuss, L., Pinkse, J., \& Figge, F. (2014). Cognitive frames in corporate sustainability: Managerial sensemaking with paradoxical and business case frames. Academy of Management Review, 39(4), 463-487. https://doi.org/10.5465/amr.2012.0341

Hajek, P., Olej, V., \& Myskova, R. (2014). Forecasting corporate financial performance using sentiment in annual reports for stakeholders' decision-making. Technological and Economic Development of Economy, 20(4), 721-738. https://doi.org/10.3846/20294913.2014.979456 
Huang, H. H., Lobo, G. J., Wang, C., \& Xie, H. (2016). Customer concentration and corporate tax avoidance. Journal of Banking \& Finance, 72, 184-200. https://doi.org/10.1016/j.jbankfin.2016.07.018

Irvine, P. J., Park, S. S., \& Ylldızhan, Ç. (2016). Customer-base concentration, profitability, and the relationship life cycle. The Accounting Review, 91(3), 883-906. https://doi.org/10.2308/accr-51246

Itzkowitz, J. (2013). Customers and cash: How relationships affect suppliers' cash holdings. Journal of Corporate Finance, 19, 159-180. https://doi.org/10.1016/j.jcorpfin.2012.10.005

Jia, D., \& Bian, S. (2019). Can the negative tone of prospectus predict post-ipo performance? Finance Forum, 10, 60-69 (in Chinese).

Kahneman, D., \& Tversky, A. (1979). Prospect theory: An analysis of decision under risk. Econometrica, 47(2), 263-292. https://doi.org/10.1111/1468-0262.00439

Kelepouris, T., Miliotis, P., \& Pramatari, K. (2008). The impact of replenishment parameters and information sharing on the bullwhip effect: A computational study. Computers \& Operations Research, 35(11), 3657-3670. https://doi.org/10.1016/j.cor.2007.04.004

Kim, J., \& Lee, W. (2019). How does board structure affect customer concentration? https://doi.org/10.2139/ssrn.3238644

Krolikowski, M., \& Yuan, X. (2017). Friend or foe: Customer-supplier relationships and innovation. Journal of Business Research, 78, 53-68. https://doi.org/10.1016/j.jbusres.2017.04.023

Li, F. (2010). The information content of forward-looking statements in corporate filings - a naive bayesian machine learning approach. Journal of Accounting Research, 48(5), 1049-1102. https://doi.org/10.1111/j.1475-679X.2010.00382.x

Lind, J. T., \& Mehlum, H. (2010). With or without u? The appropriate test for a u-shaped relationship. Oxford Bulletin of Economics and Statistics, 72(1), 109-118. https://doi.org/10.1111/j.1468-0084.2009.00569.x

Loughran, T., \& Mcdonald, B. (2011). When is a liability not a liability? Textual analysis, dictionaries, and 10-Ks[J]. The Journal of Finance, 66(1), 35-65. https://doi.org/10.1111/j.1540-6261.2010.01625.x

Lu, L., \& Pohkam, W. (2019). Performance feedback, financial slack and the innovation behavior of firms. Asia Pacific Journal of Management, 36(4), 1079-1109. https://doi.org/10.1007/s10490-018-9634-4

Luo, B., Luo, C., Ge, J., \& Zhang, D. (2016). The moderating effects of slack on the relationship between ambidextrous strategy and performance: Evidence from high-tech firms in China. Journal of Business Economics and Management, 17(5), 734-748. https://doi.org/10.3846/16111699.2016.1193043

March, J. G. (1991). Exploration and exploitation in organizational learning. Organization Science, 2(1), 71-87. https://doi.org/10.1287/orsc.2.1.71

Minakov, V. F., Lobanov, O. S., Makarchuk, T. A., Minakova, T. E., \& Leonova, N. M. (2017). Dynamic management model of innovations generations. In 2017 XX IEEE International Conference on Soft Computing and Measurements (SCM), (pp. 849-852). St. Petersburg, Russia. IEEE. https://doi.org/10.1109/SCM.2017.7970743

Ocasio, W. C. (1995). The enactment of economic adversity - a reconciliation of theories of failureinduced change and threat-rigidity. Research in Organizational Behavior, 17, 287-331.

Osiyevskyy, O., \& Dewald, J. (2015). Explorative versus exploitative business model change: The cognitive antecedents of firm-level responses to disruptive innovation. Strategic Entrepreneurship Journal, 9(1), 58-78. https://doi.org/10.1002/sej.1192

Pan, J., Yu, M., Liu, J., \& Fan, R. (2020). Customer concentration and corporate innovation: Evidence from China. North American Journal of Economics and Finance, 54, 101284. https://doi.org/10.1016/j.najef.2020.101284

Patatoukas, P. N. (2012). Customer-base concentration: Implications for firm performance and capital markets. The Accounting Review, 87(2), 363-392. https://doi.org/10.2308/accr-10198 
Peng, X., Wang, X., \& Yan, L. (2019). How does customer concentration affect informal financing? International Review of Economics \& Finance, 63, 152-162. https://doi.org/10.1016/j.iref.2018.08.022

Shen, H., Xia, N., \& Zhang, J. (2018). Customer-based concentration and firm innovation. Asia-Pacific Journal of Financial Studies, 47(2), 248-279. https://doi.org/10.1111/ajfs.12210

Song, J., \& Wang, X. (2019). Customer concentration and management earnings forecast. Economic and Political Studies, 7(4), 454-479. https://doi.org/10.1080/20954816.2019.1667600

Ugur, N. (2013). Measuring the validity of a text based indicator for exploration and exploitation activities. In Proceedings of the $8^{\text {th }}$ European Conference on Innovation and Entrepreneurship, 2 (pp. 797806), 19-20 September 2013. Brussels, Belgium.

Uotila, J., Maula, M., Keil, T., \& Zahra, S. A. (2009). Exploration, exploitation, and financial performance: Analysis of S\&P 500 corporations. Strategic Management Journal, 30(2), 221-231. https://doi.org/10.1002/smj.738

Voss, G. B., Sirdeshmukh, D., \& Voss, Z. G. (2008). The effects of slack resources and environmentalthreat on product exploration and exploitation. Academy of Management Journal, 51(1), 147-164. https://doi.org/10.5465/amj.2008.30767373

Wang, C., Luo, B., Liu, Y., \& Wei, Z. (2016). The impact of executives' perceptions of environmental threats and organizational slack on innovation strategies. Nankai Business Review International, 7(2), 216-230. https://doi.org/10.1108/NBRI-11-2015-0029

Wang, D., Su, Z., \& Guo, H. (2019). Top management team conflict and exploratory innovation: The mediating impact of market orientation. Industrial Marketing Management, 82, 87-95. https://doi.org/10.1016/j.indmarman.2019.02.014

Wen, W., Ke, Y., \& Liu, X. (2020). Customer concentration and corporate social responsibility performance: Evidence from China. Emerging Markets Review, 46, 100755. https://doi.org/10.1016/j.ememar.2020.100755

Wu, Z., \& Peng, X. (2020). Exploratory versus exploitative innovation: SME performance implications of managerial ties and empowering leadership in China. Asian Journal of Technology Innovation, 2, 1-29. https://doi.org/10.1080/19761597.2020.1848439

Xie, D., \& Lin, L. (2015). Do management tones help to forecast firms' future performance: A textual analysis based on annual earnings communication conferences of listed companies in China. Accounting Research, 2(1), 20-27 (in Chinese).

Xie, X., \& Gao, Y. (2018). Strategic networks and new product performance: The mediating role of ambidextrous innovation. Technology Analysis \& Strategic Management, 30(7), 811-824. https://doi.org/10.1080/09537325.2017.1380790

Xu, L., Li, J., \& Zeng, D. (2017). How does knowledge network affect a firm's explorative innovation? The contingent role of R\&D collaborations. Technology Analysis \& Strategic Management, 29(9), 973-987. https://doi.org/10.1080/09537325.2016.1260105

Yu, S., \& Chen, H. (2019). External knowledge, intraorganisational networks and exploratory innovation: An empirical examination. Innovation, 22(3), 250-269. https://doi.org/10.1080/14479338.2019.1642764

Zhou, B., Li, Y., Huang, S., Guo, S., \& Xue, B. (2019). Customer concentration and corporate innovation: Effects of financing constraints and managers' expectation of Chinese Listed Companies. Sustainability, 11(10), 2859. https://doi.org/10.3390/su11102859 